\title{
The Lack of Financial Independent Elderly Peoples in the Backward Regions
}

\author{
Bakaruddin $^{1 *}$, Agus Irianto' ${ }^{2}$ Hasdi Aimon ${ }^{3}$, Idris $^{4}$, B.Herawan Hayadi ${ }^{5}$ \\ ${ }^{* 1}$ Universitas Muhammadiyah Riau, Riau, Indonesia \\ ${ }^{2,3,4}$ Universitas Negri Padang, Padang, Indonesia \\ ${ }^{5}$ Universitas IbnuSina, Batam, Indonesia \\ bakaruddin@umri.ac.id*1
}

\begin{abstract}
This study aims to reveal a number of determinants of financial not independent be the cause of the elderly in disadvantaged areas. The study was designed in the format of mixed method, wherein in the first stage of qualitative data collection to identify a number of determinants of the causes of the financial not independent elderly. All variables are declared invalid later developed into quantitative data collection instrument at a later stage. The results of different Kruskal-Wallis test was applied to see the differences between the determinants of independent elderly and elderly are not independent. Then performed logistic regression analysis to see the effect of each determinant to provide empirical evidence on the probability not independent elderly. The results showed that the only factor of land ownership, health.
\end{abstract}

Keywords

Financial Not independent, Elderly

Article Received: 10 August 2020, Revised: 25 October 2020, Accepted: 18 November 2020

\section{Introduction}

Many previous studies that discuss Not Independent elderly in performing activities of daily life from the point of view of health. But it is very rare that focuses on economic issues such as financial independence of the elderly, especially in disadvantaged areas. In fact, the elderly are living in unique ways, depending on various factors such as gender, ethnic and cultural background, in areas lagging behind or not, developed countries or developing countries (WHO, 2015). A number of studies conducted in Malaysia proves that the elderly have financial independence predictor or dominant variables of different ethnic. There is only one dominant predictor that determines the financial independence of elderly Malaysia, which has a job[1][2].

In rural areas status as disadvantaged areas and disadvantaged in many aspects of life, the elderly may have to fight in a tougher situation. Geographical conditions sometimes force them to become independent in running their lives in their own way. Therefore, financial independence can not be measured with census data for not showing the nominal amount of a person's income. But measure the extent of a person's life fund without financial assistance from others, including children and family members[3][4].

Study in Malaysia in Kajang area, proving that more than half of respondents are financially independent, while $44 \%$ are dependent on their children, son or daughter-in-law, friends, neighbors or government financial assistance. financial independence of the elderly have a predictor or dominant variables of different ethnic[5][6]. Age and employment status is a significant predictor of the financial independence of the elderly in all ethnic models[7]. The study also concluded that there are various predictors of financial dependency by ethnic groups and as a result require different intervention strategies for different ethnic elderly in achieving financial independence in old age[8][9]. In other studies that education and socioeconomic status sosiallah has positive effects on the independence of the instrumental activities of daily living (IADL) (main activity in daily life)[10]. Among all elderly men showed Not Independent maksimum IADL managing money and traveling[11]. 
This study is a research venture that aims to find one or several variables or predictor can predict the financial independence of the elderly in disadvantaged areas in Indonesia which is designed in the form of mixed method (combined).

Regional districts that are geographically and society is less developed than other regions on a national scale in terms of the aspects of economy, society, human resources, public infrastructure, fiscal capacity, accessibility, and characteristics of the area known as "disadvantaged areas." The status attached by decision of the Indonesian government. For the 2015-1019 year span of Indonesia stated that nearly a third of the area in Indonesia (29\%) or covering 122 territories classified as disadvantaged areas. The condition is generally found in areas that are geographically isolated and remote as the area of border, an area of small islands, the hinterland, as well as disaster-prone areas[12]. In effect the policy of solving the problems of underdevelopment in the form of partiality, acceleration, and empowerment of the disadvantaged areas is the local government authority. However, because of the importance of this problem the Indonesian government even felt the need to form the Ministry of Rural Development since more than a decade ago.

Generally under developed areas into pockets of poverty. Simply put poverty is understood as a condition when a family has a low income and unable to meet their basic needs to grow to be better. The condition comes from their being very limited and is unable to improve their economic status[13]. They could not get a job with a decent wage because of the low educational or skill, nor could develop a profitable independent business because of lack of initial capital or assets as collateral to borrow capital from banks. They also cannot provide quality education to their children so that they are very prone to fall into the bondage of poverty also prolonged. The most interesting thing of the disadvantaged areas in Indonesia is the diversity of characteristics. One characteristic of the equation these provinces is the fact that approximately $80 \%$ of the population lives from agriculture, so that the problem of land ownership became an urgent issue. For example
Minangkabau society, the land not only serves as a source of production or income, but also has a social function where the land can reflect one's social position and status in society[14].

When comparing the elderly Indonesia and developed countries, the fundamental difference is the availability of old-age security. Until now, the government has yet to design a protection scheme overall pension security for every citizen. Enlarging the elderly population could potentially provide many benefits if resilient, healthy and productive. The elderly population is predicted to even be the second demographic bonus for Indonesia. However, making the elderly population remains healthy, resilient and productive course requires a lot of preparation and support of all parties. Other phenomena that were encountered today are elderly people who still bear the lives of their children and grandchildren even though they are married. This is evident from the data CPM noted that nearly half of the number of elderly[14], Data elderly financial independence of the most popular and frequently released officially is dependency ratio, ie the ratio between the number of elderly in the population of working age. Figures illustrate relative population of productive age who should bear the cost of the life of an elderly person. Such measurements may be useful to describe the demographic ratio. But obviously not going to explain anything if it is related the ability of an elderly meet the cost of his life with kelansiaan limited by them[15].

Poverty is not synonymous with financial independence, if poverty is always measured by nominal income or the average expenditure index, while financial independence does not have the financial baku. Kemandirian parameter is a measure of subjective abstract individuals concerned about the way she generates income and the income allocated in such a way without need help from others. From an economic perspective, the government encouraged the parents to be financially independent as long as possible. To what extent do parents rely financially well-documented, but little research has focused on the perspective of ethnic differences[16]. This study aims to find predictors 
of financial Not Independent most dominant elderly in disadvantaged areas[17].

\section{Conceptualization Financial Not Independent}

It is hard for us find explanations defined by default on the term "financial Not Independent", but maybe a little bit easily find the meaning of "financial independence." The process of financial independence begins when a person enters adulthood. Financial independence takes longer under the current socio-economic conditions, which resulted in a lower social status for the transition to be an adult (Cote and Bynner, 2008). Financial independence as one of the main criteria for adulthood is defined as the ability to finance their own lives (Arnett, 2000). Not Independent or financial independence does not discuss the amount of money in a certain nominal, also does not use government statistics such as per capita expenditure as benchmark, Cost of living index is very easy person's individual different types of needs they certainly are not the same. Their choice of lifestyle, a certain nominal purchasing power of a currency is also easy to be different in different regions.

In this study, the term "financial" refers to the understanding of the science of financial management, namely the management of the function "fundraising" and "allocation of funds" (Brigham, 2007). Both of these functions is implemented in the context of the financial organization and daily housekeeping. But in this study, only a limited financial Not Independent Not Independent in generating income for life necessities. Though admittedly, there was found some elderly people who do notindependent in allocating its own earnings, but it's more appropriately called a unique case which is difficult to generalize. Chan (2010) to identify the presence or absence of financial independence an elderly person who so respondents using a single measure, by asking questions; "Mr / Ms, today whom financial providers your major? The answer may be" myself "," my partner "," boys and girls "," brother "and" others. "All possible answers then grouped into two main categories, independent and dependent. Criticism of independent measurements such as this needs to be asked because it may be biased by being asked is the main financial provider. An elderly are most likely to answer; "I own", but in fact his income was not enough so he still need additional funds in the form of government assistance, for example. That is, with the methodology used by Chan and colleagues, which is not a self-sufficient elderly, will be recorded as an independent elderly. Likewise, the elderly who receive assistance from their children, they may have their own adequate income, they tend to say "my children help" for reasons of pride in children who are already successful or better social domicile. Respondents will then be recorded as not independent. they tend to say "my children help" for reasons of pride in children who are already successful or better social domicile. Respondents will then be recorded as not independent. They tend to say "my children help" for reasons of pride in children who are already successful or better social domicile. Respondents will then be recorded as not independent.

We conclude that it is impossible to know the financial independence of the elderly by simply asking a single question. The method used is to ask a number of questions with face to face interviews with respondents. In this study, the financial independence of thought is based on the extent to which a person does not need financial assistance from other parties in obtaining the financial resources to be allocated to finance his life. Thus, the elderly who are not at all income or income elderly but still must be given sufficient financial assistance in order to finance life income, income elderly themselves but income was controlled by the other party will be classified as seniors who are not independent.

\section{Finding Cause Financial Not Independent}

Not many studies that examine the factorsthat determines financial Not Independent an elderly person. Moreover, to find a great sebuahteori relevant for disadvantaged areas. Several previous studies finding different predictor variables such as economic factors are found as significant predictors toward financial freedom, assets, employment status, and educational attainment (Xiao, Chatterjee and Kim, 2014). The 
comparative study in Malaysia proves that not all of the three ethnic groups (Malay, Chinese and Indian) have the same financial Not Independent predictors in the old days. Because of the different lines in the experience of life and socio-economic status, the older Malaysians of different ethnic descent has a level of financial independence is also different (Chan, 2010).

Several psychological factors such as selfefficacy, economics, money management skills, and problemsolving skills are also positively associated with financial freedom. Family economic factors such as parental income, ownership, and financial help reduce the level of financial independence of young people. Additional analysis showed that the level of financial independence of college graduates is higher than those who never attended or are currently in college, but did not differ from those who have dropped out of school. Common and different factors related to the freedom of finances

This research ial young adults also identified among the four groups of education (Xiao, Chatterjee and Kim, 2014) tried to identify some of the factors that can or can not be used as predictors of independence of the elderly. This becomes very important, especially when formulating policies on the empowerment of the elderly. Currently in the national program of empowerment of the elderly in Indonesia, one of which is the provision of business credit scheme for the elderly, called KUBE. Whether it was right or not? Results of this research may be able to answer that question. Observation and then conducted from January 2017 to July 2017 in the area of West Pasaman, West Sumatra province's status as disadvantaged areas according to a decree of Minister In Affairs of the Republic of Indonesia. This area used as the unit of analysis for interesting coincidence is also inhabited by the three dominan ethnic, Minang, BatakMandailing, and Java, and a number of macroeconomic indicators the Development areas that are relatively poor. Human development index is only 63.3, average life expectancy of 65.7 years, and $0.86 \%$ of females and $2.41 \%$ of men are illiterate. Expenditure per capita is only US \$ 784 548, with the proportion of non-food expenditures $40.69 \%$
(CBS, 2016). The research strategy and then designed with two stages, where in the early stages of qualitative research conducted, and the second stage of quantitative methods to confirm or strengthen the research on qualitative stage. In the first phase depth interviews were conducted by means of face to face to the elderly of the three ethnic already confirmed are not financially independent. The information obtained through the village with indicators of respondent indeed existed as a recipient of government assistance. Samples were taken at enclave inhabited jointly by all three ethnic groups, with consideration of the carrying capacity of the external environmental factors are relatively equal obtained byEleven people with snowball sampling technique.

Although unstructured interviews with respondents, but the discussion remains focused on the two or three causes of financial Not Independent in old age based on experience and their opinions. Opinions or perceptions of respondents first about the cause Not Independent elderly respondents always ask again to the next as an alternative answer. when three respondents stating relatively the same reason, then that reason be used as a predictor variable of the study. The results of the interview concluded nine valid variables that pass the test of triangulation, namely age, marital status, gender, ethnicity, home ownership, land tenure, employment status, educational attainment, and health. The nine variables are then developed into a set of questionnaires as a data collection instrument.

\section{Quantitative Proof}

The second phase of the study is to collect the sequence data for all variables that are already identified in the qualitative phase. The study population was all the elderly in all regions of West Pasaman. When the first stage of the respondents only the elderly who are not independent course, at this second stage the respondent could have autonomy finansialataupun elderly who have no financially independent. Only nine predictor variables were included in the questionnaire. Variable financial independence remains to be explored by the enumerator with a 
structured interview to be able to know with certainty whether the respondent entered independent or not independent groups.

Enumerators managed to collect 96 respondents. Fifty-six percent of them are not self-sufficient elderly, the remaining $44 \%$ are self-sufficient elderly in financial aspects. Recapitulation

Table 1. Test Kolmogorov-Smirnov

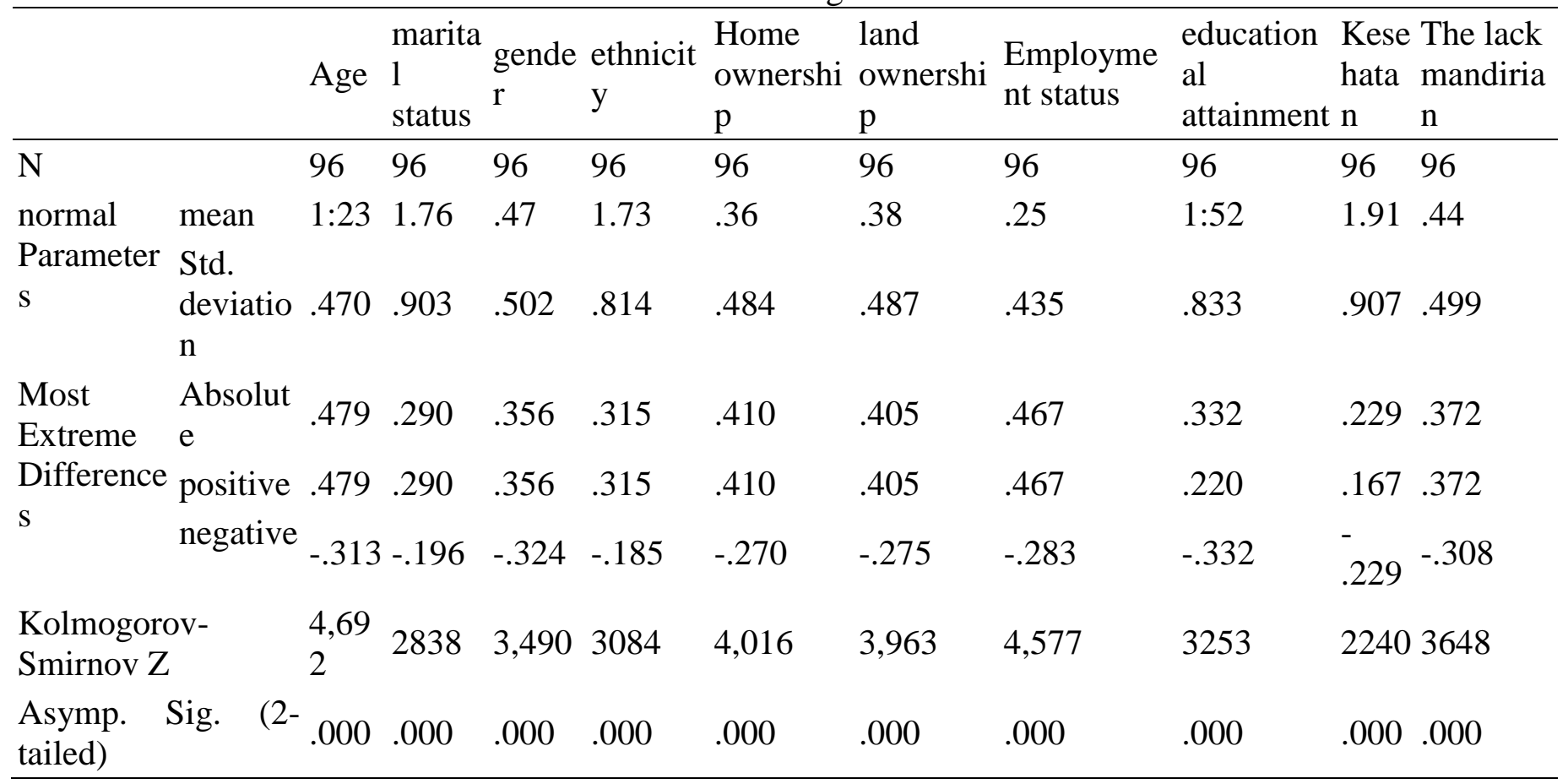

Kruskal-Wallis test was used to compare data between independent elderly with the elderly are not independent. Table 2 shows that three variables that have significant differences (Asymp. Sig. <0.05), namely land tenure, health (in the opinion of the person concerned), and educational attainment. These three variables are in fact could be an indicator of the most dominant distinguishing between the elderly are not selfcontained with independent elderly in disadvantaged areas.

Six other variables, ethnic groups, home ownership, age group, marital status, gender, and employment status proved unable to demonstrate respondent data for all variables were then tested the normality. Kolmogorov- Smirnov Test Results (Table 1) shows that all variables have not normal distribution (Asymp test Sig <0.05). This gives a signal that the data should be analyzed with nonparametric statistics.

Table 2. Kruskal Wallis

\begin{tabular}{|c|c|c|c|c|c|c|c|c|c|}
\hline & Age & $\begin{array}{l}\text { Marital } \\
\text { status }\end{array}$ & gender & ethnicity & $\begin{array}{l}\text { Home } \\
\text { ownership }\end{array}$ & $\begin{array}{l}\text { land } \\
\text { ownership }\end{array}$ & $\begin{array}{l}\text { Employment } \\
\text { status }\end{array}$ & $\begin{array}{l}\text { educational } \\
\text { attainment }\end{array}$ & Health \\
\hline $\begin{array}{l}\text { Chi- } \\
\text { square }\end{array}$ & 08 & .190 & 3,128 & 889 & .515 & 26819 & 1,396 & 11433 & 14065 \\
\hline
\end{tabular}

a significant difference between the elderly are not self-contained with independent elderly. Until this stage can already be concluded that the ownership of land, education attainment, and health become independent determinant of whether or not one of the seniors in the study areas. Therefore, these three variables can of course be used as a predictor to predict the independence of the elderly. Does government policy by giving it the right business loan scheme? While we can already argued, the elderly, it only takes land, education and health in order to have financial independence. 


\begin{tabular}{llllllllll} 
Df & 1 & 1 & 1 & 1 & 1 & 1 & 1 & 1 & 1 \\
$\begin{array}{l}\text { Asymp. } \\
\text { Sig. }\end{array}$ & .341 & .663 & .077 & .766 & .473 & .000 & .237 & .001 & .000 \\
\hline
\end{tabular}

How far these three predictors could affect the independence of the elderly? Answer to this question is very important to formulate a public policy. Because independence is a dichotomous variable, then the analysis using binary logistic regression or regression is the most logical choice.

The results of this quantitative analysis give a lot of information additional. The results of data analysis in Table 3 indicate that the elderly have land, have the chance almost nine times more likely to become self-sufficient elderly in earning for living expenses than those who do not own land $($ Odds ratio $=\operatorname{Exp}(B))$. Similarly to two times greater health, and educational one and a half times. Third dominant predictor variables were found in this study is actually an essential component to improve Human Development Index shows the classification of areas that are still poor.

Table 3. Logistic regression results Variable Phase 1: Tenure, Health, Education

\begin{tabular}{llllllll}
\hline & & B & SE & Wald & Df & Sig. & Exp (B) \\
\hline \multirow{5}{*}{ phase 1a } & KepLahan & 2,192 & .559 & 15370 & 1 & .000 & 8955 \\
& Health & .767 & .299 & 6,573 & 1 & .010 & 2,154 \\
& Education & .409 & .355 & 1,326 & 1 & .250 & 1505 \\
& constants & -3219 & .828 & 15122 & 1 & .000 & .040 \\
\hline
\end{tabular}

Ideally, the local government immediately fix these three things to anticipate the growing number of elderly are not self-sufficient in the future. But when there are financial constraints, local governments in the study area have an alternative policy to intervene in the situation. Value Sig. Table 1 gives the signal priority, where the Sig. The smallest is the most important predictor variables that must take precedence. In this case, the issue of land ownership has the highest priority for further action.

When there are budget constraints, for example, the government can only intervene through two variables:

Table 4. Logistic Regression with 2 Predictors

\begin{tabular}{lllllll}
\hline \multicolumn{6}{c}{ Variables in the Equation: Variable Phase 1- Tenure, Health } \\
\hline \multicolumn{1}{c}{ B } & SE & Wald & df & Sig. & Exp (B) \\
\hline KepLahan & 2,409 & .536 & 20173 & 1 & .000 & 11124 \\
Health & .813 & .298 & 7424 & 1 & .006 & 2254 \\
constants & -2746 & .688 & 15906 & 1 & .000 & .064 \\
\hline
\end{tabular}

Table 4 would lower a scientific formula on the financial independence of elderly in West Pasaman as follows:

$\mathrm{P}=\exp (-2.746+2.409+0.813$ KepLahan Health) $/ 1+\exp (-2.746+2.409+0.813$ KepLahan Health).

It takes a comprehensive mapping to formulate a policy to make independent elderly. Suppose of government social database known; Nuramah an elderly grandmother who lives in a remote village in West Pasaman, have land, very good health. Then have land given weight $=1$, health is very good $=3$. If incorporated into the model equation above, then:

$\mathrm{P}=\exp (-2.746+(2.409 \times 1)+(0,813 \times 3)) / 1+$ $\exp (-(-2.746+(2.409 \times 1)+(0,813 \times 3))$ $\mathrm{P}=0.891$ or $89.1 \%$ 
$\mathrm{P}$ is an indicator probabalitas, thus Grandma Nuramah likely to become self-sufficient elderly people in the financial aspect was $89.1 \%$.

Another example:

Pak Wagimantidak have land $=0$, Health Poor $=$ 1 ,

$\mathrm{P}=\exp (-2.746+(2.409 \times 0)+(0.813 \times 1)) / 1+$

$\exp (-(-2.746+(2.409 \times 0)+(0.813 \times 1))$

$\mathrm{P}=0.126$ or $12.6 \%$
His chances of becoming self-sufficient elderly only $12.6 \%$. While the elderly are not likely to become self-sufficient in earning amounted to $87.4 \%$.

The last model fittest shows that three variables are declared having different power significantly to Not Independent elderly in bivariate analysis, only the ownership of land became the most consistent predictors.

Table 5. Logistic regression with a single predictor

\begin{tabular}{llllllll} 
& & B & SE & Wald & df & Sig. & Exp (B) \\
\hline Step 1a & KepLahan & 2,442 & .504 & 23495 & 1 & .000 & 11,500 \\
& constants & -1190 & .305 & 15189 & 1 & .000 & .304 \\
\hline
\end{tabular}

The results of this analysis can be expressed in a binary regression model as follows:

$\mathrm{P}=\exp (-1.190+2.442$ KepLahan $) / 1+\exp (-$ $1.190+2.442$ KepLahan).

\section{Discussion}

Life in old age is often determined by the loss of 'prosperity' which is usually held at a younger age. Income and wealth are likely to be affected when a person reaches old age. The majority of older people, especially those who rely on the physical ability to do the job or any other economic activity, experienced a reduction in income as they left the prime working age. Health deterioration causes loss of physical strength that significantly affect their job performance. It can be said that they are threatened by the uncertainty of revenue which negatively affect their welfare. Similar conditions also occur among pension recipients. Pension amount is much smaller than their initial income, they did not receive their normal benefits as employees. Therefore, it can be appreciated that the amount of income they get is much lower now than when they were in the prime working age. These conditions are undeniably bring a reduction in quality of life among the majority of parents.

Facing the amount of revenue that is insufficient, most parents rely on a decent life on their children. Many elderly people live with their offspring or siblings who are responsible for meeting all their needs. Affluent families have no problems in meeting the needs of the elderly. Others, which are lagging in their rural places of origin, must rely on remittances from their offspring in urban areas, as confirmed by a study in three rural areas in three provinces in Indonesia (Kreager, 2006). Living survive more difficult if the financial situation of the spring they also unsatisfactory, thereby causing difficulty in sending money regularly to their parents who are elderly. In this case, surrounding communities play an important role in providing support for the elderly, especially in the service of their daily diet. The economic crisis that hit the nation in 1997, creating difficulties for parents. Since many factories and companies have to lay off their employees, more people, including those who have the primary responsibility to economically support their parents become unemployed. Losing a job, which leads to losing money almost certainly affect not only their immediate family, but also affect the lives of their parents' dependents left behind. Found that parents often sacrificed because not a high priority (Koesoebjono and Sarwono, 2003).

The economic crisis that hit the nation in 1997, creating difficulties for parents. Since many factories and companies have to lay off their employees, more people, including those who have the primary responsibility to economically 
support their parents become unemployed. Losing a job, which leads to losing money almost certainly affect not only their immediate family, but also affect the lives of their parents' dependents left behind. Found that parents often sacrificed because not a high priority (Koesoebjono and Sarwono, 2003). The economic crisis that hit the nation in 1997, creating difficulties for parents. Since many factories and companies have to lay off their employees, more people, including those who have the primary responsibility to economically support their parents become unemployed. Losing a job, which leads to losing money almost certainly affect not only their immediate family, but also affect the lives of their parents' dependents left behind. Found that parents often sacrificed because not a high priority (Koesoebjono and Sarwono, 2003). including those who have the primary responsibility to economically support their parents become unemployed. Losing a job, which leads to losing money almost certainly affect not only their immediate family, but also affect the lives of their parents' dependents left behind. Found that parents often sacrificed because not a high priority (Koesoebjono and Sarwono, 2003). including those who have the primary responsibility to economically support their parents become unemployed. Losing a job, which leads to losing money almost certainly affect not only their immediate family, but also affect the lives of their parents' dependents left behind. Found that parents often sacrificed because not a high priority (Koesoebjono and Sarwono, 2003).

Currently, the flow of economic support between generations should not be as described. The flow could be another, not only among the rich parents but also among the group of 'ordinary'. SchroderButterfill (2004) found that in some cases parents provide financial support for families where they live. Pension or income of parents is not uncommon spent in support of the family network. Poor condition mainly coincided with the economic crisis, especially among employees who are fired. Those who have been living separately from their parents will come back and share your life with their parents in their home areas. In this case, all of the resources owned by the parent will be divided to support the whole family.

Economic support by parents to their offspring may be given indirectly. It was found among families who live with their parents who are old. If they do not live with their parents, they can not hire a housekeeper and because it is the primary responsibility of women (wives) to do all the housework, all will be needed all the time. As a consequence, there will be no time left to do other work. By having elderly parents living together, they can share the household chores, especially caring for small children. Thus, women have more time allowing them to do work outside the home.

\section{Land Ownership}

Once the importance of this land in the Minangkabau people's lives, so it is not surprising such problems often arise in terms of ownership of the land itself. After the Minangkabau ethnic occupy this area, there came from South TapanuliberetnikMandailings, Early arrival they were inseparable from the emergence Padri movement, entered the 19th century in Minangkabau (Aboe Nain, 1988; Undri, 2009). This is the first period of their arrival to Pasaman. the second period, 1930s when the Dutch colonial government built the rubber plantation sector in Pasaman. Along with the development of the plantation sector, the people of South Tapanuli come to Pasaman. The third period, 1950.

In contrast to the Minangkabau and Mandailings migration, migration of Javanese to Pasaman, not in spite of the arrival of the owners of capital to Pasaman early 1900s. Although previously, the presence of Java in West Sumatra have been there, that was taken by the Dutch as contract laborers and porters forced to work in mines (Kahin, 2005). For the Dutch colonial government to bring the owners of capital to this area can not be separated from this area has large areas and fertile plantations. In addition, their small ports as a means of support for the distribution of results. The port is the port Sasak and WaterBangis (Kato, 1986). The arrival of the owners of capital in Pasaman marked by the plantation company Ophir 1911 Syndicaat NV, NV SyndicaatOphir, Thee 
Sumatra Mij NV, NV Tapanoeli, NV Talamaoe and the company has not got a name, led by $\mathrm{C}$. Knegtmans. To labor on plantations consist of free labor Java (Java vrije) and casual workers (losseArbeiders), which generally are ethnic Malay. According to the Dutch Chamber of Commerce in Padang, at the end of 1935 workers who work in the company's Java CultuurMaatschappij NV Ophir as many as 1,710 people, as many as 142 casual workers.Early in 1936 the 1,852 workers. Labor is utilized by the Dutch company to work on the development of oil palm Ophir (Asfahrizal, 1996).

They migrate to Pasaman continued until 1960 through the transmigration program. Carrying their number from 1953 to 1968 amounted to 2,068 heads of families or 8725 people. They come from Central Java, East Java, West Java and Suriname.Mereka spread across nine locations in SeiBeremas, New Village, Koto Rajo, Pasaman, Koto Baru, Tongar, Padang Lawas, Kinali, Lepau shell (Martodirjo, 1975). Since the new order until the present time, the seizure of land is no longer among fellow ethnic, but between the planters with the local community. People feel "lost" access to land that they have hereditary. Inequality occurs, farm stands like a beacon high with its numerous benefits, people on the contrary.

Currently there are about 160,000 hectares of oil palm plantation, where about 100,000 hectares owned by the company through HakGuna Usaha (HGU) an average of 40 years. The study results represent a proof well as criticism of government policy West Pasaman district. To anticipate Not Independent society in his day is a need for regulation to maintain public ownership of land. Especially tenure by the company in the form of HGU gradually be returned to the owner communal society. The new investment from outside parties should be by way of share capital (share capital), "You have the capital, we have land, let us strive together, our results are in proportion to the initial capital for us" not by selling the land. HGU land sales or continuous administration will have direct impact on the current generation of financial independence in their old age.

\section{Health Status}

Interpretation of the disease and its significance to individuals and groups is largely a product of culture and is based on the shared experience, historical significance, and social functioning of individuals in society. That kind of physiological and psychological features associated with discomfort varies greatly from one place to another (MacLachlan, 2006). Minangkabau traditional health conceptualization can be represented as a series in which the person's physical state largely unimportant unless or until it begins to interfere with daily activities of individuals. Disease recognizable when normal activity began to feel annoyed. During allows to work and interact socially in the normal way, the person is considered healthy (Tas'ady, Fanany and Fanany, 2013).

Very many, individuals of both sexes and all ages are marked health due to the absence of disease. Many also suggest that adherence to social norms is also an aspect of health and, conversely, that the disease may be a sign of social behavior or ways of speaking are not uncommon. Older respondents also felt that having enough money for their needs is an important aspect of health. This may reflect their personal experiences in times of economic difficulties, especially in the 1950s to the 1970 s when the economy is very unstable and the government's priorities centered on infrastructure funding to support development across the country (see Dick et al, 2002).

\section{Level of Education}

Elderly aged 72 years or more have certainly born before Indonesia's independence. In the colonial period condensed with discrimination, where all masyarakatdiberi educational opportunities. Until the early $60 \mathrm{~s}$ is still a difficult time to obtain formal education. This picture seems to be similar to what happened in Malaysia. They have little opportunity to receive formal education and thus, level of education attained by respondents is relatively low. Four out of ten respondents have no formal education and the educational attainment of the highest to the middle school. With the level of lower educational attainment, 
parents in Malaysia have limited economic opportunities, and this in turn affects their ability to continue to work

\section{Conclusion}

It should be acknowledged that this study is only done in older people who do not senile and still can communicate well and limited to a small number of people from one area only. Thus, the samples may not be able to represent all the elderly on their health level. However, it was found that the land as an economic resource people in underdeveloped areas, education, health is an important component in human development. The results of this study seem to fit with sejumlahindikator macro-regional development were observed.

\section{References}

[1] G. Hoffmann and L. Matysiak, "Exploring game design for the financial education of millenials," 2019 11th Int. Conf. Virtual Worlds Games Serious Appl. VS-Games 2019 - Proc., p. 1DUUMY, 2019, doi: 10.1109/VS-Games.2019.8864517.

[2] M. Zhou, "Short term prediction method of financial crisis based on artificial intelligence," Proc. - 2020 Int. Conf. Intell. Transp. Big Data Smart City, ICITBS 2020, pp. 1026-1029, 2020, doi: 10.1109/ICITBS49701.2020.00228.

[3] H. Ye and H. Feng, "On S.OA-based architecture of financial supervision information system," 2010 7th Int. Conf. Serv. Syst. Serv. Manag. Proc. ICSSSM' 10, pp. 957-961, 2010, doi: 10.1109/ICSSSM.2010.5530105.

[4] M. Shoaib, T. Elbrandt, R. Dragon, and J. Ostermann, "Altcare : Safe Livingfor Elderly People," pp. 0-3.

[5] J. B. Knox, E. M. Pereira, A. Sousa, and D. E. Dow, "Activity Monitoring System to Support Elderly Independent Living," 2019 IEEE 10th Annu. Ubiquitous Comput. Electron. Mob. Commun. Conf. UEMCON 2019, pp. 0495-0498, 2019, doi:

10.1109/UEMCON47517.2019.8992988.
[6] D. Zhang et al., "Development of a lowcost smart home system using wireless environmental monitoring sensors for functionally independent elderly people,' 2017 IEEE Int. Conf. Robot. Biomimetics, ROBIO 2017, vol. 2018-January, pp. 153158, 2018, doi: 10.1109/ROBIO.2017.8324410.

[7] Bakaruddin, Z. Azmi, and B. H. Hayadi, "Design of expert system to determine stock investment using forward chaining method," J. Adv. Res. Dyn. Control Syst., vol. 10, no. 7 Special Issue, pp. 18691873, 2018.

[8] "Living for Elderly," no. Iccmc, pp. 505508, 2020.

[9] W. Ruan, "Unobtrusive human localization and activity recognition for supporting independent living of the elderly," 2016 IEEE Int. Conf. Pervasive Comput. Commun. Work. PerCom Work. 2016, pp. 31-33, 2016, doi: 10.1109/PERCOMW.2016.7457085.

[10] G. K. H. Pang, "Health monitoring of elderly in independent and assisted living," 2012 Int. Conf. Biomed. Eng. ICoBE 2012, no. February, pp. 553-556, 2012, doi: 10.1109/ICoBE.2012.6178978.

[11] X. Li, D. Luo, F. Zhao, Y. Li, and H. Luo, "Sensor fusion-based infrastructure independent and agile real-time indoor positioning technology for disabled and elderly people," 2015 2nd Int. Symp. Futur. Inf. Commun. Technol. Ubiquitous Heal. Ubi-HealthTech 2015, pp. 31-35, 2015, doi: 10.1109/UbiHealthTech.2015.7203328.

[12] D. J. Hewson et al., "Development of a monitoring system for physical frailty in independent elderly," Proc. Annu. Int. Conf. IEEE Eng. Med. Biol. Soc. EMBS, pp. 6215-6218, 2013, doi: 10.1109/EMBC.2013.6610973.

[13] T. H. Tan, M. Gochoo, F. R. Jean, S. C. Huang, and S. Y. Kuo, "Front-Door Event Classification Algorithm for Elderly People Living Alone in Smart House Using Wireless Binary Sensors," IEEE Access, vol. 5, pp. 10734-10743, 2017, doi: 10.1109/ACCESS.2017.2711495. 
[14] O. Fiser, L. Rejfek, and V. Brazda, "On forward and backward scattering from fog and rain drops," Proc. 13th Conf. Microw. Tech. Com. 2013 - MAREW 2013 Microw. Radio Electron. Week 2013, no. 3, pp. 152-155, 2013, doi: 10.1109/COMITE.2013.6545060.

[15] R. S. Aboul-Yazeed and A. El-Bialy, "Lower back MRI region-based segmentation for computer-aided systems," Middle East Conf. Biomed. Eng. MECBME, vol. 2016-November, pp. 106109, 2016, doi: 10.1109/MECBME.2016.7745419.

[16] M. T. I. Rumengan, J. Rumengan, and ..., “... With Work Motivation As Intervening Variables To Performance of University Employees Batam Using Sem-Pls (Partial Least Square ...," ... Stud. Manaj. ..., vol. 24, no. 06, pp. 5579-5589, 2020, [Online]. Available:

http://ejurnal.univbatam.ac.id/index.php/M anajerial/article/view/232.

[17] A. Wanto et al., "Forecasting the Export and Import Volume of Crude Oil, Oil Products and Gas Using ANN," J. Phys. Conf. Ser., vol. 1255, no. 1, 2019, doi: 10.1088/1742-6596/1255/1/012016. 